\title{
Control of homeostatic proliferation by regulatory T cells
}

\author{
Shiqian Shen, ${ }^{1}$ Yi Ding, ${ }^{1}$ Carlos E. Tadokoro, ${ }^{1}$ Danyvid Olivares-Villagómez, ${ }^{1}$ \\ Marlin Camps-Ramírez,1 Maria A. Curotto de Lafaille,1,2 and Juan J. Lafaille1,2
}

\author{
${ }^{1}$ Molecular Pathogenesis Program, Skirball Institute for Biomolecular Medicine, and \\ 2Department of Pathology, New York University School of Medicine, New York, New York, USA.
}

\begin{abstract}
Homeostatic proliferation of $T$ cells leads to the generation of effector/memory cells, which have the potential to cause harm to the host. The role of Tregs in the control of homeostatic proliferation is unclear. In this study we utilized mice that either harbor or lack Tregs as recipients of monoclonal or polyclonal T cells. We observed that while Tregs completely prevented cell division of $T$ cells displaying low affinity for self ligands, they had a less marked, albeit significant, effect on cell cycle entry of $T$ cells displaying higher affinity. The presence of Tregs resulted in a lower accumulation of $T$ cells, enhanced apoptosis, and impaired differentiation to a cytokine-producing state. We conclude that Tregs play a major role in the control of homeostatic proliferation.
\end{abstract}

\section{Introduction}

Homeostatic proliferation of T cells, also known as lymphopeniainduced proliferation or, perhaps more appropriately, spontaneous proliferation (1), is an important property of the adaptive immune system. Proliferation of T cells in lymphopenic conditions, caused by chronic diseases, or treatments such as thymectomy or irradiation, is pivotal to keep a relatively constant number of T cells (2-5). Factors that support $\mathrm{T}$ cell homeostatic proliferation include MHC-peptide/ TCR interactions and cytokines such as IL-7 and IL-15 (6-19).

Previous work has highlighted the importance of TCR signaling in homeostatic proliferation (20-24). TCR signaling reflects the intrinsic affinity of the TCR for self peptide/MHC ligands, the ligand density, and the contribution of the coreceptors CD4 or CD8. Ge et al. described that homeostatic proliferation of T cells was only slightly enhanced by weakly reactive self peptides, whereas potent agonistic peptides promoted much more rapid proliferation (21). Competition experiments between $T$ cells with different TCR affinities for self ligands led Kieper et al. to suggest that the strength of the TCR affinity determines the rate of survival and homeostatic proliferation (24). Competition experiments were also performed by Kassiotis et al., who determined that at early time points, $T$ cells with higher avidity for self ligands had a competitive advantage. However, this advantage did not lead to the disappearance of the low-avidity $\mathrm{T}$ cells, whose frequency reached a plateau at late time points (23).

Mechanisms that prevent some individual $\mathrm{T}$ cell clones from being too dominant are in place. For instance, homeostatic proliferation is limited by the presence of $\mathrm{T}$ cells expressing the same TCR or, in a polyclonal setup, by the presence of a large memory polyclonal repertoire $(1,25-27)$.

Nonstandard abbreviations used: $\mathrm{MBP}$, myelin basic protein; $\mathrm{MBP} / \mathrm{R}^{+}$mice, $\mathrm{MBP}-$ specific TCR transgenic mice on a RAG ${ }^{+}$background; MBP/R- mice, MBP-specific TCR transgenic mice on a $\mathrm{RAG}^{-/-}$background; OVA, chicken ovalbumin; OVA/R ${ }^{+}$ mice, DO11.10 OVA-specific TCR transgenic mice on a RAG ${ }^{+}$background; OVA/R- mice, DO11.10 OVA-specific TCR transgenic mice on a RAG ${ }^{-1}$ background; RAG, recombinase activating gene; sf, scurfy.

Conflict of interest: The authors have declared that no conflict of interest exists.

Citation for this article: J. Clin. Invest. 115:3517-3526 (2005).

doi:10.1172/JCI25463.
Homeostatic proliferation occurs in a number of physiological and pathological situations. Newborn $(28,29)$ and aging individuals support homeostatic proliferation, as do individuals afflicted with chronic infections that alter thymic output or individuals undergoing chemotherapy. A recent finding linking homeostatic proliferation and autoimmunity in the NOD mouse highlights the dangerous effect of producing effector/memory $\mathrm{T}$ cells by homeostatic proliferation (30). In the BB rat and congenic strains, spontaneous diabetes always cosegregates with lymphopenia (31, 32). Furthermore, it has been reported that homeostatic proliferation contributes to the onset of autoimmune gastritis (33) and influences $\mathrm{T}$ cell repertoire in rheumatoid arthritis (34). In a tumor model, it was shown that the antitumor responses depended on homeostatic expansion of a polyclonal $\mathrm{T}$ cell population within lymph nodes (35). In transplantation, allospecific T cells expanding after lymphoablative treatments were involved in the failure to achieve tolerance (36).

Tregs are one of the key components of the adaptive immune system (37-43), but whether Tregs play an important role in the control of homeostatic proliferation remains controversial (3, 44). In this study, we used 2 experimental models of mice that either harbor Tregs or lack Tregs to study the homeostatic proliferation of transferred monoclonal or polyclonal $\mathrm{CD}^{+} \mathrm{T}$ cells. We demonstrate that Tregs affect homeostatic proliferation by affecting cell division, the survival of cells that have undergone proliferation, and the functional differentiation into cytokineproducing effector/memory $\mathrm{T}$ cells.

\section{Results}

Absence of homeostatic proliferation of OVA-specific T cells in myelin basic protein-specific TCR transgenic mice on a $R A G^{+}$background. In order to address the role of competition and the role of Tregs in the control of homeostatic proliferation, we utilized 2 TCR transgenic strains, DO11.10 anti-OVA TCR (45) and anti-myelin basic protein (anti-MBP) TCR (46). In both transgenic lines, we studied mice on recombinase activating gene ${ }^{+}\left(\mathrm{RAG}^{+}\right)$and $\mathrm{RAG}^{-/-}$backgrounds (abbreviated hereafter as $/ \mathrm{R}^{+}$and $/ \mathrm{R}^{-}$, respectively). As previously indicated by functional in vivo studies, both $M B P / R^{-}$ and OVA/ $\mathrm{R}^{-}$mice lack Tregs, which are present in $\mathrm{MBP} / \mathrm{R}^{+}$and 


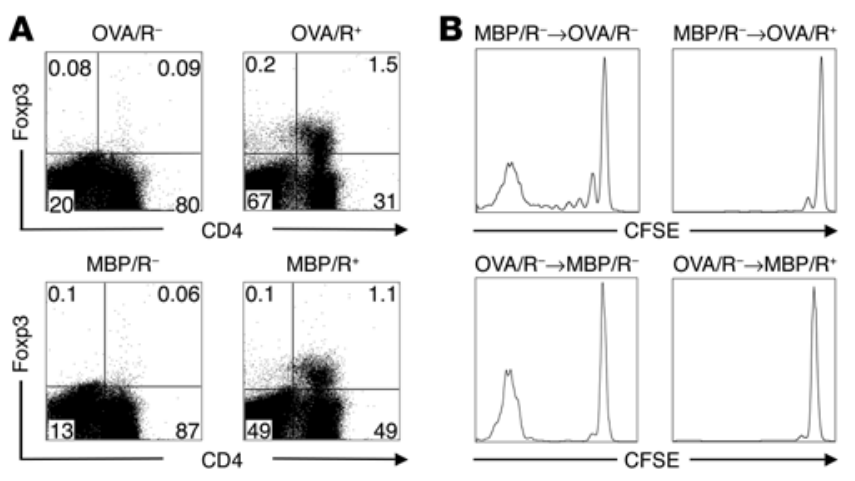

Figure 1

Control of homeostatic proliferation correlates with the presence of Tregs in MBP/R+ and OVA/R+ mice. (A) Presence of naturally occur-

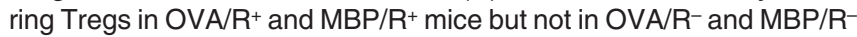
mice. Lymph node cells from 4- to 7-week-old OVA/R-, OVA/R+, MBP/R-, and $\mathrm{MBP} / \mathrm{R}^{+}$mice were stained with anti-CD4 and anti-Foxp3, gated on live lymphocytes. Numbers indicate frequency among total live lymphocytes. Data are representative of 10 mice. (B) OVA/R ${ }^{-}$, but not OVA/R+ mice, support homeostatic proliferation of MBP-specific $T$ cells, whereas $M B P / R^{-}$, but not $M B P / R^{+}$mice, support homeostatic proliferation of OVA-specific T cells. Top row: $1 \times 10^{7} \mathrm{CFSE}-$ labeled splenocytes from $\mathrm{H}-2^{\mathrm{d} / \mathrm{u}}$ Thy1.1 $\mathrm{MBP} / \mathrm{R}^{-}$donor mice were transferred into $\mathrm{H}-2^{\mathrm{d} / \mathrm{u}}$ Thy $1.2 \mathrm{OVA} / \mathrm{R}^{-}$(left) or $\mathrm{H}-2^{\mathrm{d} / \mathrm{u}}$ Thy $1.2 \mathrm{OVA} / \mathrm{R}^{+}$(right) recipient mice; 12 days after transfer, recipients were sacrificed and singlecell suspensions were made from brachial, inguinal, and axillary lymph nodes. Plots show cells gated on Thy $1.1^{+}$anti-MBP TCR $\left(3 \mathrm{H} 12^{+}\right)$cells. Data are representative of 4 mice. Bottom row: $1 \times 10^{7} \mathrm{CFSE}$-labeled splenocytes from $\mathrm{H}-2^{\mathrm{d} / \mathrm{u}}$ Thy1.1 OVA/R- donor mice were transferred into $\mathrm{H}-2^{\mathrm{d} / \mathrm{u}}$ Thy1.2 MBP/R- (left) or $\mathrm{H}-2^{\mathrm{d} / \mathrm{u}}$ Thy1.2 MBP/R+ (right) recipient mice; 12 days after transfer, recipients were sacrificed, and singlecell suspensions were made from brachial, inguinal, and axillary lymph nodes. Plots show cells gated on Thy $1.1^{+} \mathrm{KJ} 1.26^{+}$cells. Data are representative of 4 mice.

OVA $/ \mathrm{R}^{+}$mice (46-49). This was confirmed using intracellular Foxp3 staining (Figure 1A and Supplemental Figure 1; supplemental material available online with this article; doi:10.1172/ JCI25463DS1). The anti-OVA and anti-MBP TCR transgenic systems mentioned above were used in combination, both in MHC haplotype $\mathrm{H}-2^{\mathrm{d} / \mathrm{u}}$ to create an environment that selects the OVA and the MBP TCR-expressing T cells (48). Splenocytes from $\mathrm{H}-2^{\mathrm{d} / \mathrm{u}}$ OVA/ $\mathrm{R}^{-}$donors were transferred into $\mathrm{H}-2^{\mathrm{d} / \mathrm{u}} \mathrm{MBP} / \mathrm{R}^{-}$or $\mathrm{MBP} / \mathrm{R}^{+}$ hosts; reciprocally, splenocytes from $\mathrm{H}-2^{\mathrm{d} / \mathrm{u}} \mathrm{MBP} / \mathrm{R}^{-}$donors were transferred into $\mathrm{H}-2^{\mathrm{d} / \mathrm{u}} \mathrm{OVA} / \mathrm{R}^{-}$or $\mathrm{OVA} / \mathrm{R}^{+}$hosts. Interestingly, only OVA/ $\mathrm{R}^{-}$recipient mice supported homeostatic proliferation of transferred anti-MBP T cells, whereas OVA $/ \mathrm{R}^{+}$mice did not (Figure $1 \mathrm{~B}$ ). Similarly, $\mathrm{MBP} / \mathrm{R}^{-}$recipient mice, but not $\mathrm{MBP} / \mathrm{R}^{+}$ mice, supported homeostatic proliferation of transferred antiOVA T cells (Figure 1B). Control experiments in which donor cells from OVA/ $\mathrm{R}^{-}$mice were transferred into OVA $/ \mathrm{R}^{-}$recipient mice or donor cells from $\mathrm{MBP} / \mathrm{R}^{-}$mice were transferred into $\mathrm{MBP} / \mathrm{R}^{-}$ recipient mice showed no proliferation (Supplemental Figure 2), supporting the key role played by intraclonal competition in homeostatic proliferation (25-27).

It is important to note that the fraction and absolute number of $\mathrm{T}$ cells that express a repertoire encoded by the endogenous TCR genes is very small in TCR transgenic $\mathrm{RAG}^{+}$mice. We showed previously that only about $2 \%$ of the T cells in anti-MBP TCR transgenic $\mathrm{RAG}^{+}$mice express endogenous TCR $\alpha$ and $\beta$ chains, and $10 \%$ of the T cells express dual TCRs consisting mostly of the transgenic TCR $\alpha$ and $\beta$ chains together with a second TCR $\alpha$ chain encoded by the endogenous TCR $\alpha$ locus (50). Thus, the repertoire encoded by the endogenous TCR loci is reduced by approximately 10 -fold in anti-MBP RAG ${ }^{+}$mice compared with wild-type mice. Despite their highly reduced $\mathrm{T}$ cell repertoire, anti-MBP RAG ${ }^{+}$mice could prevent homeostatic proliferation of OVA/ $\mathrm{R}^{-}$cells very effectively.

To assess whether the control of homeostatic proliferation correlated with the control of autoimmunity, a large number of $\mathrm{CD}^{+}$ T cells $\left(3 \times 10^{7} ;>95 \%\right.$ purity) from $\mathrm{H}-2^{\mathrm{d} / \mathrm{u}} \mathrm{MBP} / \mathrm{R}^{+}$or $\mathrm{MBP} / \mathrm{R}^{-}$ mice were transferred into nontransgenic $\mathrm{H}-2^{\mathrm{d} / \mathrm{u}} \mathrm{RAG}-1^{-/-}$ hosts and, after 1 month, a second transfer was done with CFSElabeled $\mathrm{CD}^{+} \mathrm{T}$ cells from $\mathrm{H}-2^{\mathrm{d} / \mathrm{u}} \mathrm{OVA} / \mathrm{R}^{-}$mice. All mice that received cells from $\mathrm{MBP} / \mathrm{R}^{-}$donors developed EAE about 30-50 days after the first transfer, while none of the mice that received cells from $\mathrm{MBP} / \mathrm{R}^{+}$donors developed the disease during the observation period (day 80 after first transfer; Figure 2A). These results confirm our previous findings on the existence of cells with Treg function within the endogenous $\mathrm{CD} 4^{+} \mathrm{T}$ cell population of $\mathrm{MBP} / \mathrm{R}^{+}$mice. Interestingly, when the second (OVA-specific) group of transferred cells was tracked, we observed that antiOVA CD $4^{+} \mathrm{T}$ cells only proliferated in recipients pre-filled with $\mathrm{CD}^{+} \mathrm{T}$ cells from $\mathrm{MBP} / \mathrm{R}^{-}$but not $\mathrm{MBP} / \mathrm{R}^{+}$mice (Figure $2 \mathrm{~B}$ ). Thus, there is a good correlation between the existence of a Treg population that prevents EAE and the prevention of homeostatic proliferation in the recipient mice.

The mere presence of memory $T$ cells is not sufficient to restrain bomeostatic proliferation of $T$ cells of a different TCR specificity. One important feature of cells that undergo homeostatic proliferation is the change from naive to memory phenotype. Thus, T cells could transit from one potential niche occupied by naive cells into a niche occupied by memory cells. It has been postulated that the existence of memory $\mathrm{T}$ cells could nonspecifically restrain homeostatic proliferation by preventing transferred $T$ cells from entering the niche occupied by memory cells (51). Since in unimmunized $\mathrm{MBP} / \mathrm{R}^{+}$ or OVA $/ \mathrm{R}^{+}$mice, there is always a fraction of $\mathrm{T}$ cells displaying a memory phenotype $(52,53)$, it was of interest to determine whether the existence of large numbers of memory $\mathrm{T}$ cells could prevent proliferation of naive T cells of a different TCR specificity. Nontransgenic $\mathrm{H}-2^{\mathrm{d} / \mathrm{u}} \mathrm{RAG}-1^{-/-}$mice received $\mathrm{T}$ cells from $\mathrm{H}-2^{\mathrm{d} / \mathrm{u}} \mathrm{OVA} / \mathrm{R}^{-}$ mice. As expected, after 2 months the transferred CD $4^{+}$cells had extensively proliferated and acquired a memory phenotype (Figure 3A). After 2 months, $\mathrm{T}$ cells from $\mathrm{H}-2^{\mathrm{d} / \mathrm{u}} \mathrm{MBP} / \mathrm{R}^{-}$mice were transferred to these hosts. Despite predictions based upon a memory $\mathrm{T}$ cell niche model, we observed that pre-filling recipients with antiOVA memory $\mathrm{T}$ cells did not prevent homeostatic proliferation of anti-MBP T cells and their transition into a memory phenotype (CD44hi) (Figure 3B). It is therefore apparent that the small population of memory $\mathrm{T}$ cells present in $\mathrm{MBP} / \mathrm{R}^{+}$or OVA/ $\mathrm{R}^{+}$hosts could not account for nonspecifically controlling the homeostatic proliferation of naive anti-OVA or anti-MBP T cells; instead, there may be specific properties associated with the cells that suppress homeostatic proliferation.

Control of homeostatic proliferation of monoclonal CD $4^{+} T$ cells by Tregs. We have thus far demonstrated that in $\mathrm{MBP} / \mathrm{R}^{+}$mice there is population of cells expressing endogenous TCR that prevents autoimmunity and homeostatic proliferation and also that the control of homeostatic proliferation can not be explained by the mere presence of memory $\mathrm{T}$ cells in $\mathrm{MBP} / \mathrm{R}^{+}$mice; a role for Tregs in controlling homeostatic proliferation is therefore likely. 

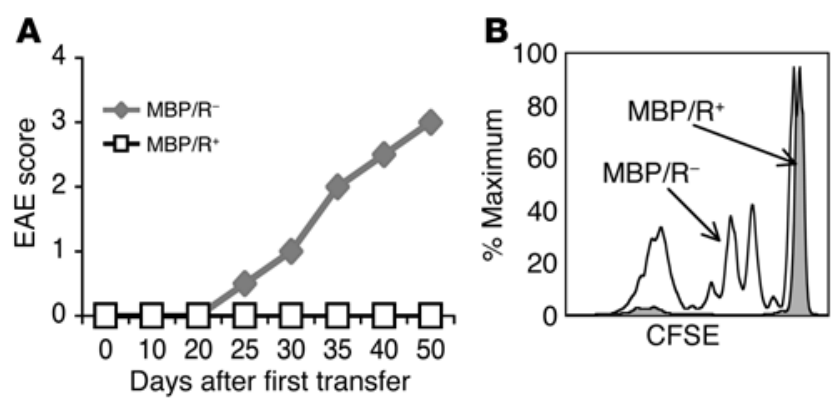

\section{Figure 2}

Endogenous $\mathrm{CD}^{+} \mathrm{T}$ cells in $\mathrm{MBP} / \mathrm{R}^{+}$mice prevent both spontaneous $E A E$ and homeostatic proliferation. (A) In MBP/ $R^{+}$mice, $T$ cells expressing TCRs encoded by endogenous TCR genes protect from EAE. $3 \times 10^{7} \mathrm{CD}^{+} \mathrm{T}$ cells purified from $\mathrm{H}-2^{\mathrm{d} / \mathrm{u}} \mathrm{MBP} / \mathrm{R}^{-}(n=5)$ or $\mathrm{MBP} / \mathrm{R}^{+}(n=7)$ mice were transferred into nontransgenic $\mathrm{H}-2^{\mathrm{d} / \mathrm{u}}$ RAG-1/-- recipient mice, and the incidence and severity of EAE in the recipients were monitored. (B) In MBP/ $R^{+}$mice, T cells expressing TCRs encoded by endogenous TCR genes prevent the homeostatic proliferation of OVA-specific T cells. $3 \times 10^{7} \mathrm{CD}^{+} \mathrm{T}$ cells purified from $\mathrm{H}-2^{\mathrm{d} / \mathrm{u}} \mathrm{MBP} / \mathrm{R}^{-}(n=4)$ or $\mathrm{MBP} / \mathrm{R}^{+}(n=3)$ mice were transferred into nontransgenic $\mathrm{H}-2^{\mathrm{d} / u} \mathrm{RAG}-1^{-/-}$recipient mice. Thirty days after the first transfer, recipient mice were transferred with $1 \times 10^{7}$ CFSElabeled splenocytes from $\mathrm{H}-2^{\mathrm{d} / \mathrm{u}} \mathrm{OVA} / \mathrm{R}^{-}$mice. Twelve days after the second transfer, single-cell suspensions of lymph node cells from the recipient mice were made and stained with anti-CD4 and anti-OVA TCR clonotypic antibody KJ1.26 for FACS analysis. Shown is the CFSE dilution of gated $\mathrm{CD} 4^{+} \mathrm{KJ} 1.26^{+}$cells. Filled histogram: representative recipient of MBP/ $\mathrm{R}^{+} T$ cells; open histogram, representative recipient of $M B P / R^{-} T$ cells.

As previously noted, one important difference between TCR transgenic $\mathrm{RAG}^{+}$and TCR transgenic $\mathrm{RAG}^{-/-}$mice is the absence of Tregs in the latter type of mice (Figure 1A and Supplemental Figure 1). In the anti-MBP TCR transgenic system, $100 \%$ of $\mathrm{MBP} / \mathrm{R}^{-}$mice spontaneously develop EAE, whereas less than $1 \%$ of $\mathrm{MBP} / \mathrm{R}^{+}$mice do. This protection from EAE is due to Tregs expressing endogenous TCR genes that are present in $\mathrm{MBP} / \mathrm{R}^{+}$mice and absent in $\mathrm{MBP} / \mathrm{R}^{-}$mice $(46,50,52)$. We have previously shown that transfer of polyclonal $\mathrm{CD}^{+} \mathrm{CD} 25^{-} \mathrm{T}$ cells resulted in protection of $\mathrm{MBP} / \mathrm{R}^{-}$ mice from EAE, and, more recently, we showed that, in monoclonal TCR transgenic systems, there is an IL-2-dependent in vivo conversion of CD $4^{+} \mathrm{CD} 25^{-} \mathrm{T}$ cells to $\mathrm{CD} 4^{+} \mathrm{CD} 25^{+}$Foxp $3^{+}$Tregs $(54,55)$.

We therefore sought to determine whether $\mathrm{CD} 4^{+} \mathrm{CD} 25^{+}$Tregs could control homeostatic proliferation. Two and a half million $\mathrm{CD} 4^{+} \mathrm{CD} 25^{+}$Tregs or $\mathrm{CD} 4^{+} \mathrm{CD} 25^{-}$cells were purified from $\mathrm{H}-2^{\mathrm{d} / \mathrm{u}}$ syngeneic wild-type mice and transferred into $\mathrm{H}_{-} 2^{\mathrm{d} / \mathrm{u}} \mathrm{MBP} / \mathrm{R}^{-}$mice. Three days later, CFSE-labeled splenocytes from $\mathrm{H}_{-} \mathrm{2}^{\mathrm{d} / \mathrm{u}} \mathrm{OVA} / \mathrm{R}^{-}$ donors were transferred into these $\mathrm{H}^{-} \mathrm{2}^{\mathrm{d} / \mathrm{u}} \mathrm{MBP} / \mathrm{R}^{-}$mice. We observed that the homeostatic proliferation of OVA/R- cells was significantly reduced in recipient mice pre-transferred with Tregs compared with mice pre-transferred with non-Tregs (Figure 3C). In this short time window (3 days), conversion of CD $4^{+} \mathrm{CD} 25^{-}{ }^{-F o x p} 3^{-}$ $\mathrm{T}$ cells into $\mathrm{CD}^{+} \mathrm{CD} 25^{+} \mathrm{Foxp}^{+}$Tregs has not yet taken place (55), thereby explaining why $\mathrm{CD} 4^{+} \mathrm{CD} 25^{-} \mathrm{T}$ cells were inefficient in the control of homeostatic proliferation. Thus, CD $4^{+} \mathrm{CD} 25^{+}$Tregs suppress the homeostatic proliferation of $\mathrm{CD} 4^{+} \mathrm{T}$ cells.

Control of homeostatic proliferation of polyclonal CD $4^{+} T$ cells by Tregs. Having shown that Tregs control homeostatic proliferation of TCR transgenic monoclonal CD $4{ }^{+} \mathrm{T}$ cells, we next explored wheth- er homeostatic proliferation of polyclonal CD $4^{+} \mathrm{T}$ cells is subject to control by Tregs. In order to demonstrate the role of Tregs in homeostatic proliferation, we used Foxp3-deficient scurfy $(s f)$ mice, which lack Tregs (56-58). Although it would have been desirable to use recipient mice with a full $\mathrm{T}$ cell repertoire and no Tregs, we could not use non-TCR transgenic sf mice as healthy recipients for our study, due to the fact that they die of severe lymphoproliferative disease at about 3 weeks of age and already show clear physical signs of disease at age of about 2 weeks. By crossing $s f$ mice to TCR transgenic mice, progression of this disease was significantly delayed, allowing a safe time window for our studies. Thus, $\mathrm{H}-2^{\mathrm{b} / \mathrm{b}} \cdot s f$ mice (59) were crossed to $\mathrm{H}-2^{\mathrm{u} / \mathrm{u}} \mathrm{MBP} / \mathrm{R}^{+}$mice to generate $\mathrm{H}-2^{\mathrm{u} / \mathrm{u}}$ $\mathrm{MBP} / \mathrm{R}^{+} . s f$ mice. Due to the limited TCR repertoire, these mice showed no signs of scurfy until age 7-8 weeks, making them suitable recipients that lack Tregs but remain healthy well beyond the duration of our study. In fact, at the young age that we used $\mathrm{MBP} / \mathrm{R}^{+} . s f$ mice, they displayed none of the typical characteristics of scurfy, showing normal numbers of $\mathrm{T}$ cells, normal distribution of activation markers, and no enhanced cytokine production, unlike the nontransgenic sf animals (Supplemental Figure 3, A-C). Furthermore, $\mathrm{MBP} / \mathrm{R}^{+} . s f$ mice have a TCR repertoire encoded by the endogenous TCR loci that is similar to that of $\mathrm{MBP} / \mathrm{R}^{+}$mice, except that they lack Tregs (Supplemental Figure 3D).

CFSE-labeled polyclonal CD4 T cells from wild-type $\mathrm{H}-2^{\mathrm{u} / u}$. Thy1.1 mice were transferred into $\mathrm{H}-2^{\mathrm{u} / \mathrm{u}} \mathrm{MBP} / \mathrm{R}^{+}$mice, which have endogenous Tregs, or into $\mathrm{H}-2^{\mathrm{u} / \mathrm{u}} \mathrm{MBP} / \mathrm{R}^{+} . s f$ mice, which lack endogenous Tregs. Seven days after transfer, only a small percentage of donor-derived cells in $\mathrm{MBP} / \mathrm{R}^{+}$recipient mice had entered cell cycle and diluted their CFSE, whereas a much higher percentage of donor-derived cells became CFSE ${ }^{\text {low }}$ in $\mathrm{MBP} / \mathrm{R}^{+} . s f$ recipients (Figure 4A); at day 12, the percentage of cells in the $\mathrm{CFSE}^{\text {low }}$ population was also higher in the MBP/ $\mathrm{R}^{+} . s f$ mice than in the $\mathrm{MBP} / \mathrm{R}^{+}$mice (Figure $4 \mathrm{~B}$ ). Importantly, the non-lymphopenic MBP/R $\mathrm{R}^{+}$.sf mice and lymphopenic TCR $\alpha \beta^{-/-}$mice showed a similar fraction of CFSE ${ }^{\text {low }}$ cells (Figure 4B). When the absolute number of donor-derived cells recovered from $\mathrm{MBP} / \mathrm{R}^{+} . s f$ and $\mathrm{MBP} / \mathrm{R}^{+}$host mice was compared, there were about twice as many cells of donor origin in $\mathrm{MBP} / \mathrm{R}^{+}$.sf mice than in $\mathrm{MBP} / \mathrm{R}^{+}$ mice (Figure 4C). These results clearly indicated that Tregs could suppress homeostatic proliferation.

Studies of the behavior of AND TCR transgenic T cells, which display an unusually high homeostatic proliferation, led Barthlott and coworkers to propose that $\mathrm{T}$ cells with high homeostatic expansion potential (CD5 5 i see below) could regulate the expansion of naive $\mathrm{T}$ cells, irrespective of markers commonly associated with Treg functions (51). We therefore determined whether $\mathrm{MBP} / \mathrm{R}^{+}$mice contained more $\mathrm{CD}^{\text {hi }} \mathrm{T}$ cells than $\mathrm{MBP} / \mathrm{R}^{+} . s f$ mice, thus explaining the efficient control of homeostatic proliferation in $\mathrm{MBP} / \mathrm{R}^{+}$ host mice without the need to invoke a role for a professional Treg population. Importantly, the T cell population encoded by endogenous TCR loci (transgenic TCR clonotype negative) in $\mathrm{MBP} / \mathrm{R}^{+} . s f$ mice expresses high levels of CD5, comparable to the endogenous $\mathrm{T}$ cell population in $\mathrm{MBP} / \mathrm{R}^{+}$mice (Figure $4 \mathrm{D}$ ). In both $\mathrm{MBP} / \mathrm{R}^{+}$and $\mathrm{MBP} / \mathrm{R}^{+} . s f$ mice, the endogenous $\mathrm{T}$ cell population expresses levels of CD5 higher than the transgenic $T$ cell population (Figure 4D). Regarding the frequency of the endogenous $\mathrm{T}$ cell population, at the beginning of the experiment, when animals were about 3 weeks of age, it was similar in both types of mice and remains so until the end of the experiment 12 days later (Supplemental Figure 3C). Eventually, in old (7-8 weeks) MBP/ $\mathrm{R}^{+} . s f$ mice, the peripheral endog- 
A

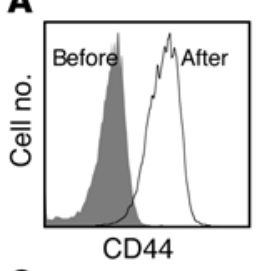

C

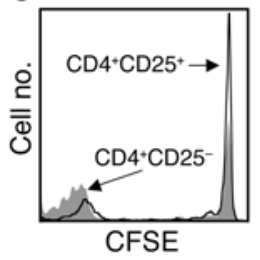

B

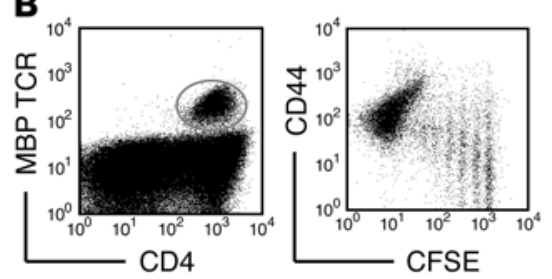

\section{Figure 3}

The mere presence of memory $T$ cells is not sufficient to prevent homeostatic proliferation of naive T cells bearing a different TCR specificity. (A) $1 \times 10^{7}$ splenocytes from $\mathrm{H}-2^{\mathrm{d} / \mathrm{u}} \mathrm{OVA} / \mathrm{R}^{-}$mice were transferred into nontransgenic $\mathrm{H}-2^{\mathrm{d} / \mathrm{u}} \mathrm{RAG}-1^{-/-}$recipient mice $(n=4)$. After 10-12 weeks, the transferred CD4+ cells acquired a CD44 hi phenotype consistent with memory T cells. Filled histogram: $\mathrm{KJ} 1.26^{+}$cells before transfer; open histogram: KJ1.26+ cells parked in nontransgenic $\mathrm{H}-2^{\mathrm{d} / \mathrm{u}}$ RAG-1 $1^{-/-}$recipient mice. (B) Subsequently, $1 \times 10^{7}$ CFSE-labeled splenocytes from $\mathrm{H}-2^{\mathrm{d} / \mathrm{u}} \mathrm{MBP} / \mathrm{R}^{-}$mice were transferred into the same recipients. Twelve days after the second transfer, single-cell suspensions of lymph node cells from the recipient mice were made and stained with anti-CD4, anti-CD44, and the anti-MBP TCR clonotypic antibody $3 \mathrm{H} 12$ for FACS analysis. The left panel shows the gate on MBP-specific T cells, and the right panel shows the highly efficient generation of MBP-specific memory T cells (CD44 ${ }^{\text {hi }}$ CFSE ${ }^{\circ}$ ). (C) Adoptive transfer of Tregs. $2.5 \times 10^{6}$ purified $\mathrm{CD} 4^{+} \mathrm{CD} 25^{+}$or $\mathrm{CD} 4^{+} \mathrm{CD} 25^{-} \mathrm{T}$ cells from $\mathrm{H}-2^{\mathrm{d} / \mathrm{u}}$ wild-type mice were transferred into $\mathrm{H}-2^{\mathrm{d} / \mathrm{u}} \mathrm{MBP} / \mathrm{R}^{-}$ recipient mice. Three days later, $1 \times 10^{7} \mathrm{CFSE}$-labeled splenocytes from $\mathrm{H}-2^{\mathrm{d} / \mathrm{u}} \mathrm{OVA} / \mathrm{R}^{-}$were transferred into the same recipients, and 12 days after the second transfer, single-cell suspensions of lymph node cells from the recipient mice were prepared and stained with anti-CD4, anti-KJ1-26 (clonotypic antibody for the OVA-specific TCR), and antiTCR $\beta$ antibodies. Plots show cells gated on CD4+KJ1-26+TCR $\beta^{+}$cells. A time gate was also used to allow the display of the same number of $\mathrm{CD} 4^{+} \mathrm{KJ} 1-26^{+}$donor-derived cells in each overlaid histogram. Data are representative of 3 mice per group.

enous $\mathrm{T}$ cell population outnumbers the population of equivalent cells in $\mathrm{MBP} / \mathrm{R}^{+}$mice and even outnumbers the transgene-encoded MBP-specific cells. Thus, combining the frequency of T cells encoded by endogenous loci with their expression of CD5, it is clear that there are comparable numbers of CD $5^{\text {hi }}$ cells in both types of mice, despite the fact that one type of recipient mice effectively controls homeostatic proliferation, while the other fails to do so (Figure 4A). These results strengthen the argument that professional Tregs are involved in the control of homeostatic proliferation.

In summary, Tregs present in $\mathrm{MBP} / \mathrm{R}^{+}$mice are capable of completely preventing homeostatic proliferation of 2 monoclonal populations of $\mathrm{T}$ cells and have a robust albeit incomplete control of the expansion of a polyclonal population of $\mathrm{T}$ cells. The reasons for this leakiness in Treg-mediated control of polyclonal $\mathrm{T}$ cell homeostatic proliferation were subsequently addressed.

$T$ cells bearing high-affinity TCRs proliferate more than $T$ cells bearing low-affinity TCRs in the presence of Tregs. It has been shown that TCR signaling is indispensable for transferred naive cells to

transit into memory phenotype upon homeostatic proliferation (19). We therefore sought to determine whether the differences in the capacity of Tregs to control homeostatic proliferation of polyclonal versus monoclonal cells were related to the TCR avidity of the expanding cells. It has been shown that the level of CD5 expression reflects the avidity of TCR-ligand interactions $(24,60$, 61). We therefore transferred CFSE-labeled polyclonal $\mathrm{CD} 4^{+} \mathrm{T}$ cells into MBP $/ \mathrm{R}^{+}$recipients and assessed the level of $\mathrm{CD} 5$ expression in the CFSE ${ }^{\text {hi }}$ and CFSElow populations. Donor-derived CFSE $^{\text {low }}$ cells expressed a higher level of surface CD5 than CFSE $E^{\text {hi }}$ cells (mean fluorescence intensity, 568 vs. 274; Figure 5A). It has been previously shown that sorted $C D 5^{\text {hi }}$ cells expand more than CD5 ${ }^{\text {low }}$ cells in sublethally irradiated recipients (61). It was therefore possible that the monoclonal $\mathrm{T}$ cell populations expanded less because they expressed low-avidity TCRs. Indeed, when the level of surface CD5 expression was analyzed in fresh $\mathrm{H}-2^{\mathrm{d} / \mathrm{u}}$ antiOVA T cells, $\mathrm{H}-2^{\mathrm{d} / \mathrm{u}}$ anti-MBP T cells, and $\mathrm{H}-2^{\mathrm{d} / \mathrm{u}} \mathrm{CD} 4^{+}$wild-type $\mathrm{T}$ cells, we observed that both anti-OVA and anti-MBP $\mathrm{T}$ cells expressed levels of CD5 that were at the lowest end of the CD5 expression curve displayed by polyclonal $\mathrm{T}$ cells from wild-type mice (Figure 5B). The correlation between avidity of TCR-ligand interaction and CD5 expression level predicts that a particular T cell would express lower levels of CD5 if it develops/lives in the presence of lower levels of self ligands. To confirm this prediction, we determined the level of CD5 expression of $\mathrm{H}-2^{\mathrm{d}}$-restricted OVA-specific $\mathrm{T}$ cells obtained from $\mathrm{H}-2^{\mathrm{d} / \mathrm{d}}$ mice (self ligands in homozygosity) and $\mathrm{H}-2^{\mathrm{d} / \mathrm{u}}$ mice (self ligands in heterozygosity). As expected, CD5 expression was higher on T cells obtained from homozygous $\mathrm{H}-2^{\mathrm{d} / \mathrm{d}}$ mice, despite the fact that $\mathrm{T}$ cells from both mice express identical TCRs and, by virtue of having the same C57BL/10 genetic background, both express the same set of genes, with no polymorphisms between them. Similarly, CD5 expression levels were higher on MBP-specific T cells obtained from homozygous $\mathrm{H}-2^{\mathrm{u} / \mathrm{u}}$ mice than $\mathrm{H}-2^{\mathrm{d} / \mathrm{u}}$ mice (Figure $5 \mathrm{C}$ ).

The results shown thus far suggested that Tregs could completely control the homeostatic proliferation of low-avidity $\mathrm{T}$ cells and incompletely that of high-avidity $\mathrm{T}$ cells. In order to demonstrate this point, polyclonal $\mathrm{CD} 4^{+} \mathrm{T}$ cells from Thy 1.1 donors were sorted into CD5 hi (high TCR avidity) and CD5 low (low TCR avidity) populations, labeled with CFSE, and transferred into non-lymphopenic Treg-harboring MBP/ $\mathrm{R}^{+}$mice or non-lymphopenic Treg-lacking MBP/ $\mathrm{R}^{+} . s f$ mice. Analysis of CFSE dilution 12 days after transfer showed that, in $\mathrm{MBP} / \mathrm{R}^{+}$recipient mice, $\mathrm{CD} 5^{\text {hi }}$ donor-derived cells proliferated more than their CD5 $5{ }^{\text {low }}$ counterparts, with about twice as many cells from the CD5 hi population becoming CFSElow (Figure 5D). In Treg-deficient $\mathrm{MBP} / \mathrm{R}^{+} . s f$ recipient mice, however, there was extensive proliferation of both $\mathrm{CD} 5^{\text {hi }}$ and $\mathrm{CD} 5^{\text {low }} \mathrm{T}$ cells (Figure $5 \mathrm{D}$ ). Thus, the role of Tregs in controlling homeostatic proliferation was more prominent in low-TCR-avidity $\mathrm{T}$ cells than in high-TCR-avidity $\mathrm{T}$ cells, explaining the differences between the total suppression of proliferation of monoclonal MBP- and OVA-specific TCR transgenic $\mathrm{H}-2^{\mathrm{d} / \mathrm{u}}$ cells and the milder, albeit significant, effect on total $\mathrm{CD} 4^{+}$cells.

Enhanced apoptosis of donor-derived $T$ cells in recipient mice that have Tregs. Although homeostatic proliferation of transferred polyclonal CD4 T cells can be detected in recipient mice that harbor Tregs, the number of donor-derived cells recovered form hosts that have endogenous Tregs was much lower (Figure 4C).

Part of the controversy surrounding whether or not Tregs play a role in the control of homeostatic proliferation could be that the effect of Tregs on cell division entry, as measured by CFSE dilution, 
A

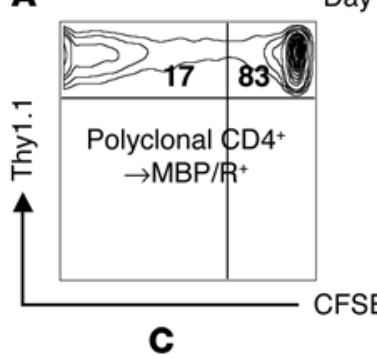

c

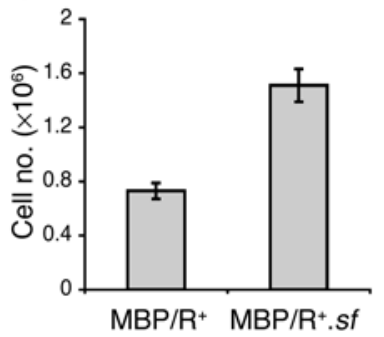

B
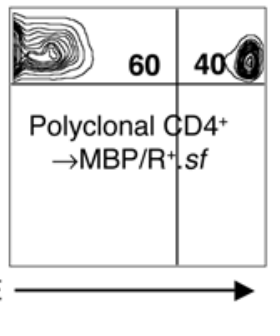

D
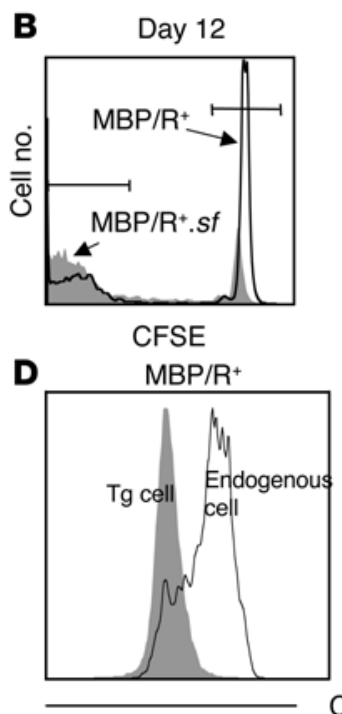
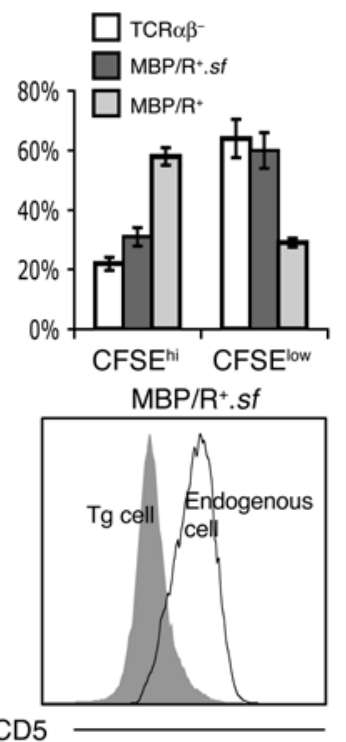

Figure 4

Tregs control the expansion of polyclonal CD4+ T cells. $1 \times 10^{7}$ CFSE-labeled splenocytes from Thy1.1 H-2u/u C57BL/10.PL mice were transferred into Thy1.2 H-2 $2^{\mathrm{u} / \mathrm{u}} \mathrm{MBP} / \mathrm{R}^{+}(n=9)$ and Thy1.2 H-2u/u MBP/R ${ }^{+} . s f(n=9)$ mice. Seven $(n=4)$ or $12(n=5)$ days after transfer, single-cell suspensions from peripheral lymph nodes were made, and cells were counted and stained for FACS analysis. (A) Analysis of cell division at day 7 after transfer, gated on donor-derived Thy $1.1+C D 4+$ cells. Left: representative MBP/R+ recipient; right: representative $M B P / R^{+} . s f$ recipient. (B) Left: overlay analysis of cell division at day 12 after transfer, gated on donor-derived Thy $1.1^{+} \mathrm{CD} 4^{+}$cells. Filled histogram: MBP/R ${ }^{+} . s f$ recipient; open histogram: MBP/R+ recipient. The horizontal lines indicate the gates. Right: quantification of the percentage of CFSEhi and CFSElow donor-derived T cells, also showing a group in which $1 \times 10^{7} \mathrm{CFSE}-$ labeled splenocytes from Thy $1.1 \mathrm{H}-2^{\mathrm{u} / \mathrm{u}} \mathrm{C} 57 \mathrm{BL} / 10 . \mathrm{PL}$ mice were transferred into nontransgenic TCR $\alpha \beta$ knockout recipients. (C) Absolute number of donor-derived cells recovered from MBP/R $\mathrm{R}^{+}$and $M B P / R^{+} . s f$ recipients at day 12 after transfer. Average \pm SEM. (D) T cells expressing TCRs encoded by the endogenous TCR loci express high levels of CD5 in both MBP/R $R^{+}$.sf and MBP/R ${ }^{+}$mice. Lymph node cells from 4-week-old Thy $1.2 \mathrm{H}-2^{\mathrm{u} / \mathrm{u}} \mathrm{MBP} / \mathrm{R}^{+}$and Thy $1.2 \mathrm{H}-2^{\mathrm{u} / \mathrm{u}} \mathrm{MBP} / \mathrm{R}^{+} . s f$ mice were stained with anti-CD4, anti-CD5, and the anti-MBP TCR clonotypic antibody 3H12. Shown is the overlay of CD5 fluorescence intensity of clonotype-positive CD4+cells (filled histogram) and clonotype-negative $C D 4+$ cells (open histogram). Left: MBP/ $\mathrm{R}^{+}$mice; right: $\mathrm{MBP} / \mathrm{R}^{+}$.sf mice. Data are representative of 4 mice per group.

may not be as dramatic as the effect of Tregs on donor-derived cell accumulation, as measured by counting the expanded cells. As we showed above, the effect on CFSE dilution is very clear on CD5 ${ }^{\text {low }}$ cells but less marked on CD5 ${ }^{\text {hi }}$ cells.

A possible reason for the discrepancy between cell division data and cell accumulation data is that Tregs could also affect the survival of transferred $\mathrm{T}$ cells. We addressed this issue by performing TUNEL analysis and annexin $\mathrm{V}$ expression analysis. Donor CD4 ${ }^{+}$ Thy1.1 T cells were transferred into $\mathrm{MBP} / \mathrm{R}^{+}$or $\mathrm{MBP} / \mathrm{R}^{+} . s f$ hosts, and, 3 days later, lymph nodes were cut for TUNEL in situ analysis. At this early time point, virtually no cell division of donor-derived cells had taken place. A higher number of TUNEL-positive Thy $1.1^{+}$ donor-derived T cells could be noted in $\mathrm{MBP} / \mathrm{R}^{+}$recipients than in Treg-deficient $\mathrm{MBP} / \mathrm{R}^{+}$.sf recipient mice (Figure $6 \mathrm{~A}$ ).

In order to better quantify the frequency of apoptotic $T$ cells, a similar experiment was performed in which fewer $T$ cells were transferred and quantification was carried out at day 12. As at the early time point, many more donor-derived cells were positive for TUNEL staining in $\mathrm{MBP} / \mathrm{R}^{+}$hosts than in $\mathrm{MBP} / \mathrm{R}^{+} . s f$ hosts (Figure $6 \mathrm{~B}$ ). Quantification of donor-derived TUNEL ${ }^{+}$cells showed $27 \%$ in $\mathrm{MBP} / \mathrm{R}^{+}$recipient versus only $4 \%$ in $\mathrm{MBP} / \mathrm{R}^{+}$.sf mice (Figure $6 \mathrm{C}$ ). In agreement with the TUNEL data, about $40 \%$ of donor-derived cells were positive for annexin $\mathrm{V}$ in $\mathrm{MBP} / \mathrm{R}^{+}$hosts, compared with only about $20 \%$ in $\mathrm{MBP} / \mathrm{R}^{+} . s f$ recipients (Figure $6 \mathrm{D}$ ). Results from both methods indicate that more donor-derived cells died by apoptosis in presence of host Tregs, an observation that, together with the differences in cell division entry, explains the different number of cells of donor origin recovered from hosts with or without Tregs.

Tregs dampen down functional naive-to-effector/memory $C D 4^{+} T$ cell differentiation. Phenotypical changes that occur on CD4 T cells upon homeostatic proliferation include upregulation of CD44 surface expression and secretion of cytokines such as IL-2, IFN- $\gamma$, and IL-4 after restimulation $(62,63)$. Our data showed that many more donor-derived CFSE ${ }^{\text {low }}$ cells accumulated in hosts without Tregs (Figure 4C), and these cells were also CD44hi (data not shown). It was therefore of interest to determine whether there was also a qualitative difference between memory $\mathrm{T}$ cells in the different hosts. In order to study this issue, $\mathrm{CD}^{+}$Thy $1.1 \mathrm{~T}$ cells were transferred into $\mathrm{MBP} / \mathrm{R}^{+}$hosts or $\mathrm{MBP} / \mathrm{R}^{+} . s f$ hosts, and, 12 days later, the production of cytokines (IL-2, IFN- $\gamma$ ) by donor-derived cells was determined by intracellular staining. There was a dramatic increase in the frequency of CFSE ${ }^{\text {low }}$ cells that produced IFN- $\gamma$ and IL-2 in MBP/ $\mathrm{R}^{+} . s f$ hosts compared with $\mathrm{MBP} / \mathrm{R}^{+}$hosts (Figure 7 ). As expected $(64,65)$, in both groups, the CFSE ${ }^{\text {hi }}$ population produced very small amounts of cytokines (Figure 7 ). These results support a role of Tregs in controlling the homeostatic proliferation-driven functional differentiation of naive to effector/memory cells.

\section{Discussion}

In the present study, we established the key contribution of Tregs in controlling homeostatic proliferation. For T cells bearing TCRs with low avidity for self ligands, the effect of Tregs 
A

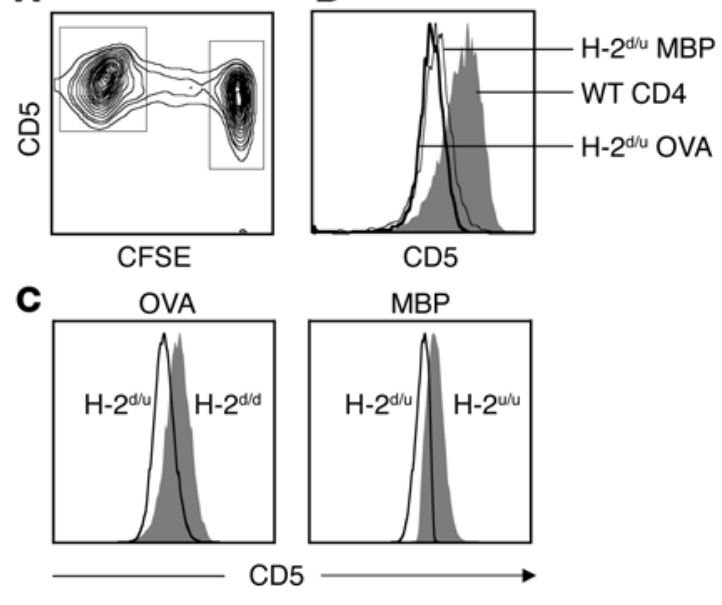

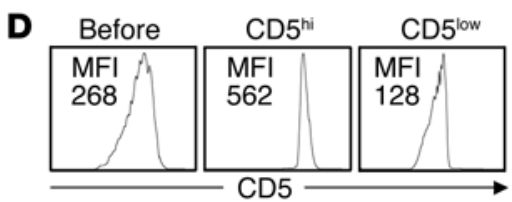

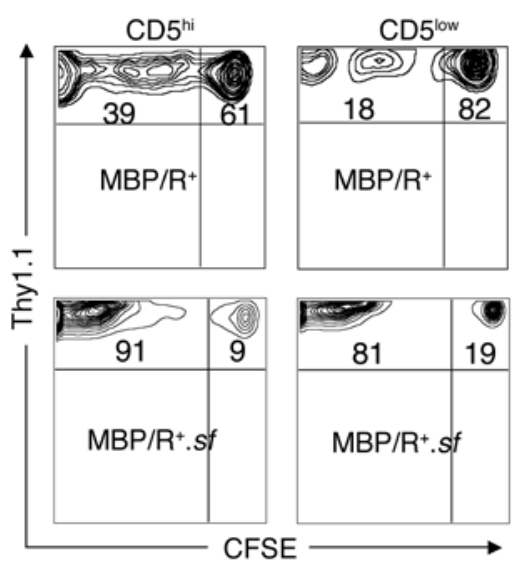

Figure 5

CD5 levels determine the extent of proliferation of CD4+ cells in non-lymphopenic, Treg-harboring MBP/R ${ }^{+}$mice. (A) High-proliferating cells display higher CD5 expression levels than low-proliferating cells. $1 \times 10^{7}$ CFSE-labeled splenocytes from Thy $1.1 \mathrm{H}-2^{\mathrm{u} / \mathrm{u}} \mathrm{C} 57 \mathrm{BL} / 10 . \mathrm{PL}$ mice were transferred into Thy1.2 H-2 $2^{\mathrm{u} / \mathrm{u}} \mathrm{MBP} / \mathrm{R}^{+}$mice. Twelve days after transfer, Thy 1.1+-gated lymph node cells were analyzed $(n=5)$. (B) H-2 $2^{\mathrm{d} / \mathrm{u}} \mathrm{OVA}-\mathrm{and}$ MBP-specific T cells express low levels of CD5. CD5 expression levels of CD4+ T cell-gated lymph node cells from 4- to 7-week-old H-2d/u OVA/R+ (thick line), MBP/R+ (thin line), or wild-type mice (filled histogram). Data are representative of 3 mice. (C) The density of self ligands affects CD5 expression levels. Left: overlay of CD5 expression levels of CD4+ $4^{+}$cells in 4- to 7-week-old H-2 ${ }^{d / d}$ OVA/R (filled histogram) or $\mathrm{H}_{-} 2^{\mathrm{d} / \mathrm{u}} \mathrm{OVA} / \mathrm{R}^{+}$ (open histogram) mice. Right: similar experiment on T cells from $\mathrm{H}-2^{\mathrm{u} / \mathrm{u}} \mathrm{MBP} / \mathrm{R}^{+}$(filled histogram) or $\mathrm{H}-2^{\mathrm{d} / \mathrm{u}} \mathrm{MBP} / \mathrm{R}^{+}$(open histogram) mice. Data are representative of 3 mice. (D) Relationship between CD5 expression levels and homeostatic proliferation in MBP/R ${ }^{+}$mice. Top row: CD5 staining before sorting (left); sorted CD5 ${ }^{\text {hi }}$ cells (middle); and sorted CD5 low cells (right). Middle row: CFSE-labeled sorted CD5 ${ }^{\text {hi }}$ and CD5 ${ }^{\text {low }}$ cells were injected into Thy $1.2 \mathrm{H}-2^{\mathrm{u} / \mathrm{u}} \mathrm{MBP} / \mathrm{R}^{+}$recipient mice ( $n=4$ mice/group). Bottom row: CFSE-labeled sorted CD5 $5^{\text {hi }}$ and $C D 5^{\text {low }}$ cells were injected into Thy 1.2 $\mathrm{H}-2^{\mathrm{u} / \mathrm{u}} \mathrm{MBP} / \mathrm{R}^{+}$.sf recipient mice ( $\left.n=4 \mathrm{mice} / \mathrm{group}\right)$. Twelve days after transfer, single-cell suspensions from peripheral lymph nodes were stained with anti-Thy1.1 and anti-CD4 for FACS analysis. MFI, mean fluorescence intensity.

was manifested as blocking of entry in cell division, whereas for T cells bearing TCRs with high avidity for self ligands, the effect of Tregs was manifested as interfering with differentiation of transferred cells from naive to memory phenotype; in addition, in the presence of Tregs, there was more apoptosis of transferred $\mathrm{CD}^{+}{ }^{+} \mathrm{T}$ cells and a reduced differentiation to cytokine-producing effector/memory cells.

The role of Tregs in controlling homeostatic proliferation is controversial $(3,44)$. Annacker and coworkers injected RAG ${ }^{-/}$ recipients with naive $T$ cells alone or together with purified $\mathrm{CD} 4{ }^{+} \mathrm{CD} 25^{+}$Tregs. Irrespective of the presence or absence of Tregs, the majority of the naive $T$ cell-derived cells were CFSE negative (i.e., divided $\geq 7$ times) 12 days after injection: $97 \%$ were CFSE negative when injected alone, whereas $78 \%$ were CFSE negative when coinjected at a 1:1 ratio with Tregs (66). Similarly, Almeida et al. observed that 10 days after injection, $95 \%$ of naive $\mathrm{T}$ cell-derived cells were CFSE negative when injected alone compared with $63 \%$ when coinjected at a 1:5 ratio with Tregs (67). $\mathrm{McHugh}$ and Shevach performed similar CFSE dilution experiments and observed no difference in the proliferation of CD25cells when injected alone into nude recipient mice or coinjected with $\mathrm{CD} 4^{+} \mathrm{CD} 25^{+}$cells at a $1: 1$ ratio, leading to the conclusion that Tregs were not important in controlling homeostatic proliferation (33). A different conclusion was reached by Ge et al. using a $\mathrm{T}$ cell-dendritic cell in vitro coculture system. These authors observed a role for $\mathrm{CD} 4{ }^{+} \mathrm{CD} 25^{+}$Tregs in controlling CFSE dilu- tion of cocultured $\mathrm{CD} 4^{+} \mathrm{CD} 25^{-}$cells (68). Finally, Prlic et al. described that $\mathrm{CD}_{25^{+}}$subset depletion in vivo failed to impact DO11.10 T cell homeostatic expansion (69). However, DO11.10 cells can also upregulate CD25 upon homeostatic expansion, and the number of $\mathrm{CD} 4{ }^{+} \mathrm{CD} 25^{+}$Tregs returns to normal after antibody clearance, reducing the period of time in which there are few Tregs and sufficiently little anti-CD25 antibody remaining to prevent interference with DO11.10 cell expansion.

Anderson and colleagues noticed that chronic GVHD in minor histocompatibilty antigen-mismatched mice was more severe in $\mathrm{RAG}^{-/-}$and in DO11.10 RAG2 ${ }^{-/-}$mice than in DO11.10 RAG2+ mice (70). They also observed that $\mathrm{CD} 4^{+} \mathrm{CD} 25^{+}$Tregs were capable of protecting hosts from chronic GVHD. These results are very consistent with our data. Although the authors suggested that it was unlikely that the protective effect of $\mathrm{CD} 4{ }^{+} \mathrm{CD} 25^{+}$Tregs in cGVHD was due to suppression of homeostatic proliferation, their article did not experimentally address this point.

Recently, it was described that the cell division of naive T cells and accumulation of CD $44^{\text {hi }} \mathrm{T}$ cells was dependent on the repertoire diversity of preexisting CD $44^{\text {hi }}$ cells, which correlated with the number of total $\mathrm{T}$ cells used to pre-fill the recipient mice (1). The authors concluded that $\mathrm{CD} 25^{+}$Tregs were not responsible for the homeostatic regulation, since, upon parking of different initial numbers of $\mathrm{CD} 4^{+} \mathrm{CD} 25^{+} \mathrm{T}$ cells, the number of cells derived from Tregs was independent of the absolute number of transferred $\mathrm{CD}^{+} \mathrm{CD} 25^{+}$cells (1). Other authors, however, showed 
A

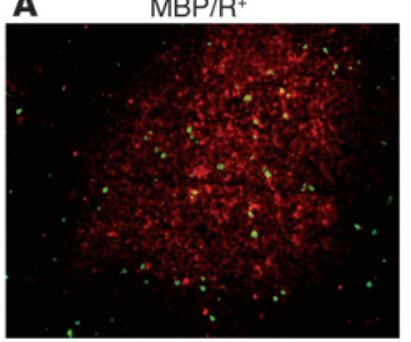

B

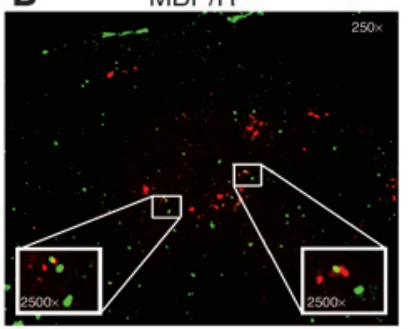

C

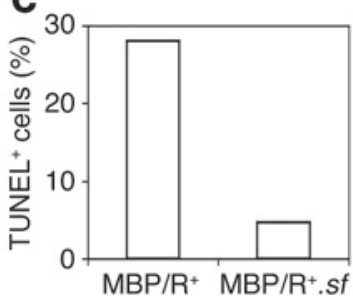

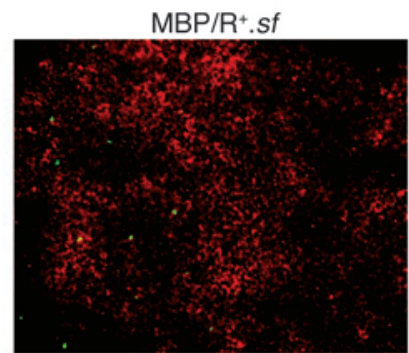

$\mathrm{MBP} / \mathrm{R}^{+} . s f$

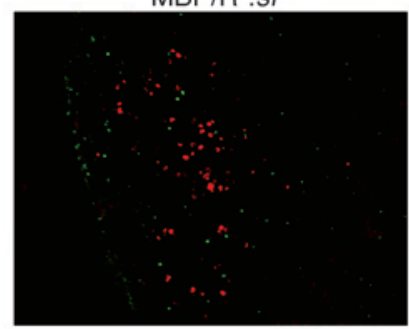

D

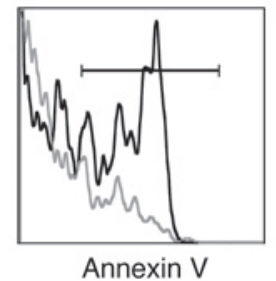

that a key parameter is the initial ratio of $\mathrm{CD} 4^{+} \mathrm{CD} 25^{+} \mathrm{T}$ cells to naive $T$ cells, rather than the absolute number of cells (67). Our previous studies indicated the importance of the TCR specificity in the generation of Tregs, as TCR transgenic T cells with MBP specificity did not naturally develop a suppressive phenotype $(46,48,50)$. Thus, transfer of too small a number of Tregs could result in a limited Treg repertoire that is impaired in the ability to reduce homeostatic proliferation, similarly to what was shown to occur with total $\mathrm{T}$ cells (1). Another possibility is that many cells that were originally $\mathrm{CD} 4{ }^{+} \mathrm{CD} 25^{+}$could have lost $\mathrm{CD} 25$ and Foxp3 expression as well as regulatory functions upon homeostatic proliferation (55).

Our analysis of monoclonal $\mathrm{T}$ cells with low avidity for self ligands (as determined by CD5 expression levels) or sorted polyclonal CD5 $5^{\text {low }}$ cells showed that CFSE dilution of these cells was dramatically blocked by Tregs. In contrast, the effect of Tregs on CFSE dilution of CD5 ${ }^{\text {hi }}$ cells was subtler. Thus, Tregs can block almost completely the division of $\mathrm{T}$ cells that display low avidity for self ligands, but cells with high avidity for self ligands enter cell

\section{Figure 7}

Endogenous Tregs reduce the functional differentiation of transferred polyclonal $\mathrm{CD}^{+} \mathrm{T}$ cells. $1 \times 10^{7} \mathrm{CFSE}-$ labeled splenocytes from Thy1.1 H-2u/u C57BL/10.PL mice were transferred into Thy1.2 H-2u/u MBP/R $\mathrm{R}^{+}(n=7)$ and Thy 1.2 $\mathrm{H}-2^{\mathrm{u} / \mathrm{u}} \mathrm{MBP} / \mathrm{R}^{+} . s f(n=4)$ mice. Twelve days after transfer, single-cell suspensions of spleen cells were stained for surface markers and intracellular cytokines. Cells were stimulated with PMA $(100 \mathrm{ng} / \mathrm{ml})$ and ionomycin $(250 \mathrm{ng} / \mathrm{ml})$ for 6.5 hours in vitro, and monensin $(3 \mathrm{nM})$ was added in the last 3.5 hours. Shown are representative plots of gated donor-derived Thy $1.1+\mathrm{CD} 4+$ cells transferred into $\mathrm{MBP} / \mathrm{R}^{+}$(left) or $\mathrm{MBP} / \mathrm{R}^{+}$.sf (right) recipient mice.

\section{Figure 6}

Enhanced apoptosis of transferred polyclonal CD4+ $\mathrm{T}$ cells in mice that harbor Tregs. (A) $1 \times 10^{7}$ purified CD4 ${ }^{+} \mathrm{T}$ cells from Thy $1.1 \mathrm{H}-2^{\mathrm{u} / \mathrm{u}}$ C57BL/10.PL mice were transferred into Thy 1.2 H-2u/u MBP/ $\mathrm{R}^{+}(n=4)$ or Thy1.2 $\mathrm{H}-2^{\mathrm{u} / \mathrm{u}} \mathrm{MBP} / \mathrm{R}^{+} . s f(n=4)$ mice. Three days after transfer, brachial, inguinal, and axillary lymph nodes were dissected for TUNEL assay. TUNEL staining: green; Thy1.1: red. (B-D) $2 \times 10^{6}$ purified $\mathrm{CD}^{+} \mathrm{T}$ cells from Thy 1.1 $\mathrm{H}-2^{\mathrm{u} / \mathrm{u}} \mathrm{C}$ 57BL/10.PL mice were transferred into Thy $1.2 \mathrm{H}-2^{\mathrm{u} / \mathrm{u}} \mathrm{MBP} / \mathrm{R}^{+}(n=4)$ and Thy $1.2 \mathrm{H}-2^{\mathrm{u} / \mathrm{u}} \mathrm{MBP} / \mathrm{R}^{+} . s f(n=4)$ mice. Twelve days after transfer, brachial, inguinal, and axillary lymph nodes were dissected. (B) TUNEL assay. One-half of the lymph nodes were frozen, and cryosections were made for fluorescent immunohistology. The 2 boxes in the left panel show, at higher magnification, donor-derived Thy $1.1^{+}$cells that were undergoing apoptosis as shown by costaining for TUNEL. (C) Quantification of Thy1.1+/TUNEL+ cells. One hundred Thy $1.1^{+}$cells were counted on lymph nodes obtained from MBP/R+ or $\mathrm{MBP} / \mathrm{R}^{+}$.sf mice. The percentage of TUNEL+ cells among Thy $1.1^{+}$cells in both types of recipient mice is plotted. (D) The other half of the lymph nodes was made into single-cell suspension, stained for Thy 1.1, CD4, and annexin V. Shown is the overlay of annexin $\mathrm{V}$ histograms on gated Thy $1.1^{+} \mathrm{CD} 4{ }^{+}$cells. Black line: $M B P / \mathrm{R}^{+}$ recipients; gray line: $M B P / R^{+}$.sf recipients. The horizontal line indicates the gate. Data are representative of 4 mice per recipient group.

cycle despite the presence of Tregs. It is possible that the threshold of TCR avidity that is permissive for cell division is higher in recipient mice that harbor more Tregs than in recipient mice that harbor fewer Tregs. Therefore, a particular CD5-intermediate T cell clone would not divide in animals that have a large number of Tregs but would divide in animals that have fewer Tregs.

One of the limitations of the CFSE technique is that it cannot reliably determine the number of rounds of division greater than 7-9 or so; therefore, it remains possible that the number of division rounds undergone by donor-derived cells is more affected than what the CFSE data show. Another reason that we observed a more pronounced Treg effect than other investigators is that, in almost all of our experiments (except those shown in Figure 3C, which were confirmatory), we employed an experimental situation in which a steady-state number of Tregs was present in the host, rather than coinjection of both naive cells and Tregs in a situation of lymphopenia. Sorted CD $4^{+} \mathrm{CD} 25^{+} \mathrm{T}$ cells are coated with antibody and/or beads, and it is not completely clear how this situation affects the fate of injected cells, particularly at early time points.
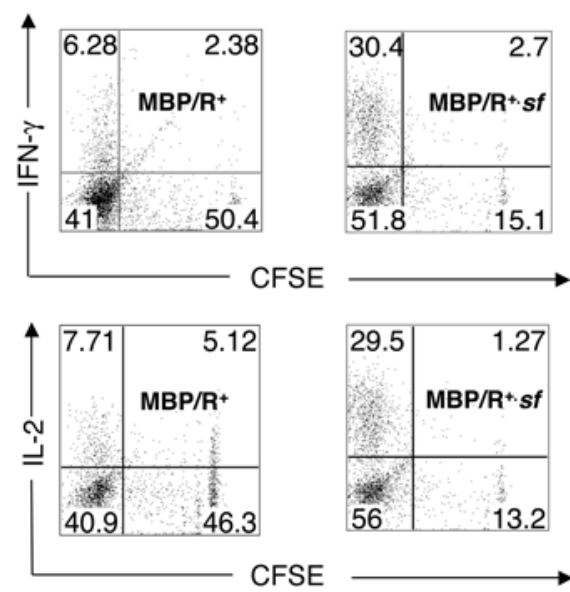

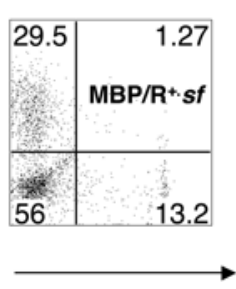


When donor-derived $\mathrm{T}$ cell accumulation was studied, we found that Tregs caused a significant reduction in cell accumulation, in agreement with previous reports $(66,67)$. This accumulation of donor-derived cells in the absence of Tregs could be at least partially explained by our results showing cells dying by apoptosis in hosts that have Tregs (Figure 6), which supports a property of Tregs that had not been shown in vivo up till now. The mechanism of the induction of apoptosis could be perforin dependent, as recently described for in vitro-activated, but not fresh, human Tregs (71), or granzyme B dependent, perforin independent (72).

The transition from naive to memory $\mathrm{T}$ cells by homeostatic proliferation is dependent on TCR signaling (19). Despite earlier disagreements regarding the functionality and stability of effector/memory $\mathrm{T}$ cells generated by homeostatic proliferation (73, 74), it has become increasingly apparent that, without exogenous antigen immunization, $T$ cells that underwent homeostatic proliferation could become fully functional memory/effector cells $(62,63,75-77)$. One fundamental property of memory $\mathrm{T}$ cells different from naive $\mathrm{T}$ cells is that they could mount a more rapid and pronounced response $(78,79)$, as shown by a rapid proliferation and cytokine secretion upon restimulation. These properties make homeostatic proliferation-derived memory $\mathrm{T}$ cells effective but dangerous if their function is not properly controlled. Therefore, it is important that Tregs are also involved in the control of homeostatic proliferation.

It has been postulated that a specialized population of Tregs is not required to control autoimmune diseases. In a homeostatic proliferation-induced inflammatory bowel disease (IBD) model, it was shown that unrelated (pigeon cytochrome $c$-specific) T cells could prevent IBD; protective capacity correlated to the expression of TCRs with high avidity for self ligands and not with the expression of markers usually associated with Tregs (51). However, our results showed that the presence of high-avidity (CD5 $\left.{ }^{\text {hi }}\right)$ cells was not sufficient to prevent homeostatic proliferation, as $\mathrm{MBP} / \mathrm{R}^{+} . s f$ mice could not control homeostatic proliferation in spite of the fact that they harbor a population of $\mathrm{CD} 5^{\text {hi }}$ cells that is of a size similar to - if not larger than - the population in $\mathrm{MBP} / \mathrm{R}^{+}$mice, which is much less permissive for homeostatic proliferation. Evidence favoring a role for specialized Tregs also comes from the $\mathrm{MBP} / \mathrm{R}^{+}$and $\mathrm{MBP} / \mathrm{R}^{-}$mouse model, in which we showed that a very small endogenous $\mathrm{CD}^{+} \mathrm{T}$ cell population could prevent both $\mathrm{EAE}$ and homeostatic proliferation. Furthermore, the onset of disease in $\mathrm{MBP} / \mathrm{R}^{-}$mice could not be prevented by rapid expansion of T cells bearing an unrelated TCR specificity (48). Most importantly, the finding of the transcription factor Foxp3, which is pivotal in the development of naturally occurring Tregs, confirms the existence of a special program associated with Treg function (56-58). It has become increasingly apparent that, under some circumstances, peripheral non-Tregs can be induced in vivo to acquire phenotypic and functional properties indistinguishable from naturally occurring $\mathrm{CD}^{+} \mathrm{CD} 25^{+} \mathrm{Foxp}^{+}$Tregs $(55,80,81)$. Furthermore, it has been long known that Tregs displaying various phenotypic differences in relation to naturally occurring Tregs can be elicited in vivo and in vitro (reviewed in refs. 40, 43, 82). It is therefore important to mention that we have only tested naturally occurring Tregs in this article.

In conclusion, our results show that Tregs have a major impact on homeostatic proliferation of T cells. The effect of Tregs is manifested as blockade of cell division entry, inhibition of effector cell differentiation, and induction of cell death.

\section{Methods}

Mice. MBP-specific TCR transgenic mice (46) and DO11.10 OVA-specific transgenic mice (45) with or without functional RAG genes have been previously described (48). All mice used in intra- and inter-clonal competition experiments were on a C57BL/10 background and $\mathrm{MHC} \mathrm{H-2} \mathrm{d} / \mathrm{u}$. All $\mathrm{MBP} / \mathrm{R}^{-}$mice used in experiments were younger than 1 month old and EAE free. Female heterozygous $s f$ mice on a C57BL/ 6 background (B6.Cg-Foxp3sf/J) were purchased from the Jackson Laboratory and backcrossed 4 generations to $\mathrm{C} 57 \mathrm{BL} / 10 . \mathrm{PL} \mathrm{H}-2^{\mathrm{u} / \mathrm{u}}$ male $\mathrm{MBP} / \mathrm{R}^{+}$ mice. Carrier heterozygous females were identified by PCR as recommended by the Jackson Laboratory. $\mathrm{H}-2^{\mathrm{u} / \mathrm{u}} \mathrm{MBP} / \mathrm{R}^{+} s f$ males $\left(\mathrm{MBP} / \mathrm{R}^{+} . s f\right)$ did not develop signs of scurfy or EAE for 7 weeks and were transferred with $\mathrm{T}$ cells at about 15-17 days of age. B6.Thy1.1 animals were purchased from Jackson Laboratory and crossed with C57BL/10.PL or C57BL/10.D2 mice to yield $\mathrm{H}-2^{\mathrm{u} / \mathrm{u}}$ and $\mathrm{H}-2^{\mathrm{d} / \mathrm{u}}$ Thy 1.1 mice on a C57BL background. Nontransgenic C57BL/10 H-2 ${ }^{\mathrm{u} / \mathrm{u}} \mathrm{TCR} \alpha^{-/-} \beta^{-/-}$mice were generated by backcrossing TCR $\alpha^{-/-} \beta^{-/-}$mice (83) with C57BL/10.PL mice for more than 10 generations. All mice were kept under specific pathogen-free conditions in individually ventilated cages (Thoren Caging Systems Inc.) at the Skirball Institute Central Animal Facility, New York University Medical Center. All procedures involving animals were approved by the New York University School of Medicine Institutional Animal Care and Use Committee.

Antibodies. Anti-MBP TCR clonotypic antibody (3H12) was generated in our laboratory as described previously (50). Anti-OVA TCR anti-clonotypic antibody (KJ1.26) was purchased from CALTAG Laboratories. The antiFoxp3 antibody was purchased from eBioscience. All other antibodies were purchased from BD Biosciences - Pharmingen.

Cell purification and sorting. Single-cell suspension of mouse splenocytes was used for purification of $\mathrm{CD}^{+}$cells by negative selection. Briefly, cells were stained with a cocktail of FITC-conjugated anti-CD8, -B220,-CD11c, -CD11b antibodies, followed by anti-FITC beads (Miltenyi Biotec). CD4 ${ }^{+}$ cells were collected after passage through a VarioMACS magnetic sorting column (Miltenyi Biotec). Typically purity was greater than $95 \%$.

For $\mathrm{CD} 5^{\text {hi }}$ and $\mathrm{CD} 5^{\text {low }}$ cell purification, $\mathrm{CD} 4^{+}$cells were prepared as described above; cells were then stained with PE-conjugated anti-CD5 antibody, and the highest and lowest $30 \%$ populations according to CD5 staining were sorted using a MoFlo cytometer (DakoCytomation), at at least $99 \%$ purity.

CFSE labeling. CFSE (Molecular Probes; Invitrogen Corp.) was added to the cell suspensions $\left(1 \times 10^{7}\right.$ cells $\left./ \mathrm{ml}\right)$ at a final concentration of $3 \mu \mathrm{M}$, $37^{\circ} \mathrm{C}$, for 10 minutes; then reaction was stopped with FCS at a final concentration of $10 \%$, and cells were washed twice with PBS and injected intravenously.

FACS analysis. Lymph nodes and spleens from recipient mice were made into single-cell suspensions in staining buffer (PBS containing 2\% FCS and $0.1 \% \mathrm{NaN}_{3}$ ). Cells were filtered and stained for 45 minutes at $4^{\circ} \mathrm{C}$ with the antibody cocktails. Samples were analyzed in a FACScalibur instrument (BD). All analysis was based on a live lymphocyte gate. Forward scatter and side scatter were plotted on a linear scale, whereas all fluorescent channels were plotted on a logarithmic scale.

For annexin $\mathrm{V}$ analysis (84), samples were stained with monoclonal antibody cocktails as described above, and, after washing, samples were incubated in a buffer solution containing $\mathrm{Ca}^{2+}(10 \mathrm{mM}$ HEPES, $150 \mathrm{mM}$ $\mathrm{NaCl}, 5 \mathrm{mM} \mathrm{KCl}, 1 \mathrm{mM} \mathrm{MgCl}, 1.8 \mathrm{mM} \mathrm{CaCl}_{2}$ ) and annexin V-PE (BD Biosciences - Pharmingen) for 10 minutes at $4^{\circ} \mathrm{C}$, in the dark. All samples were analyzed in a FACScalibur, as described above.

For intracellular cytokine staining, cells were stimulated with PMA $(100 \mathrm{ng} / \mathrm{ml})$ and ionomycin $(250 \mathrm{ng} / \mathrm{ml})$ for a total of 6.5 hours at a concentration of $1 \times 10^{6}$ cells $/ \mathrm{ml}$. In the last 3.5 hours, monensin $(3 \mu \mathrm{M})$ was 
added, cells were fixed and permeabilized with Cytofix/Cytoperm (catalog 554722), and stained with PE-conjugated mAbs to IL-4, IFN- $\gamma$, and IL-2 (all from BD Biosciences - Pharmingen).

For anti-Foxp3 staining (catalog 72-5775-40; eBioscience), samples were first stained with the antibody against the relevant surface markers, then permeabilized with Cytofix/Cytoperm at room temperature for 20 minutes, followed by another round of permeabilization with $1 \%$ paraformaldehyde plus $0.5 \%$ Tween-20 in PBS at room temperature for 30 minutes, then stained with anti-Foxp3-PE antibody at room temperature for 45 minutes.

In situ apoptosis. TUNEL assay (85) was performed. Slides containing $5-\mu \mathrm{m}$ cryosections of lymph nodes were fixed in $1 \%$ paraformaldehyde in PBS, for 30 minutes at room temperature. Slides were then washed 3 times with PBS, and a permeabilization buffer ( $1 \% \mathrm{vol} / \mathrm{vol}$ Triton X-100 and $1 \% \mathrm{wt} / \mathrm{vol}$ of sodium citrate, in deionized and distilled $\mathrm{H}_{2} \mathrm{O}$ ) was added over each slide for 2 minutes, at $4^{\circ} \mathrm{C}$. Subsequently, each slide was washed twice, and a labeling solution (In Situ Cell Detection Kit, Fluorescein; Roche Diagnostics Corp.) was added following the manufacturer's instructions. At this point, slides were incubated for 1 hour, at $37^{\circ} \mathrm{C}$, in a humidified dark chamber. At the end of this incubation, each slide was washed twice with PBS and blocked for 30 minutes at room temperature with PBS plus 10\% normal mouse serum (Cedarlane Laboratories Ltd.) plus Fc Block (BD Biosciences - Pharmingen). After blocking, PE-labeled anti-Thy 1.1 monoclonal antibody (BD Biosciences - Pharmingen) was added, and slides were incubated for 2 hours at room temperature. Finally, each slide was washed again with PBS and mounted with Fluoromount-G (SouthernBiotech). The blocking and labeling were performed in a humidified dark chamber. Images were acquired using SlideBook version 3.0.9.0 software (Intelligent Imaging Innovations Inc.) in a Axioplan 2 Zeiss microscope.

\section{Acknowledgments}

We thank Ethan Shevach, Booki Min, Tong Zhu, Daniel Mucida, and Antonio Maraver for comments and/or suggestions on the manuscript; Shi Chen, Zhonghua Chen, and Yue Wang for helpful discussions; Andreia C. Lino for CD4 T cell purification; and Eugene Friedman for help with Figure 6B display. Work in J.J. Lafaille's laboratory is supported by the NIH/National Institute of Allergy and Infectious Diseases, the National Multiple Sclerosis Society, and the Dana-Goldsmith Foundation. C.E. Tadokoro is the recipient of a Postdoctoral Fellowship from $\mathrm{CNPq}-$ Brazil.

Received for publication April 26, 2005, and accepted in revised form September 20, 2005.

Address correspondence to: Juan J. Lafaille, Molecular Pathogenesis Program, Skirball Institute for Biomolecular Medicine, New York University School of Medicine, 550 First Avenue, New York, New York 10016, USA. Phone: (212) 263-1489; Fax: (212) 263-5711; E-mail: lafaille@saturn.med.nyu.edu.

Danyvid Olivares-Villagómez's present address is: Department of Microbiology and Immunology, Vanderbilt University School of Medicine, Nashville, Tennessee, USA.
1. Min, B., Foucras, G., Meier-Schellersheim, M., and Paul, W.E. 2004. Spontaneous proliferation, a response of naive CD4 T cells determined by the diversity of the memory cell repertoire. Proc. Natl. Acad. Sci. U. S. A. 101:3874-3879.

2. Freitas, A.A., and Rocha, B. 2000. Population biology of lymphocytes: the flight for survival. Annu. Rev. Immunol. 18:83-111.

3. Jameson, S.C. 2002. Maintaining the norm: T-cell homeostasis. Nat. Rev. Immunol. 2:547-556.

4. Surh, C.D., and Sprent, J. 2002. Regulation of naive and memory T-cell homeostasis. Microbes Infect. 4:51-56.

5. Grossman, Z., Min, B., Meier-Schellersheim, M., and Paul, W.E. 2004. Concomitant regulation of T-cell activation and homeostasis. Nat. Rev. Immunol. 4:387-395.

6. Ernst, B., Lee, D.S., Chang, J.M., Sprent, J., and Surh, C.D. 1999. The peptide ligands mediating positive selection in the thymus control $\mathrm{T}$ cell survival and homeostatic proliferation in the periphery. Immunity. 11:173-181.

7. Viret, C., Wong, F.S., and Janeway, C.A., Jr. 1999. Designing and maintaining the mature TCR repertoire: the continuum of self-peptide:self-MHC complex recognition. Immunity. 10:559-568.

8. Bender, J., Mitchell, T., Kappler, J., and Marrack, P. 1999. CD4+ T cell division in irradiated mice requires peptides distinct from those responsible for thymic selection. J. Exp. Med. 190:367-374.

9. Boursalian, T.E., and Bottomly, K. 1999. Survival of naive CD4 T cells: roles of restricting versus selecting MHC class II and cytokine milieu. J. Immunol. 162:3795-3801.

10. Muranski, P., Chmielowski, B., and Ignatowicz, L. 2000. Mature CD4+ T cells perceive a positively selecting class II MHC/peptide complex in the periphery. J. Immunol. 164:3087-3094.

11. Clarke, S.R., and Rudensky, A.Y. 2000. Survival and homeostatic proliferation of naive peripheral CD4+ T cells in the absence of self peptide:MHC complexes. J. Immunol. 165:2458-2464.
12. Schluns, K.S., Kieper, W.C., Jameson, S.C., and Lefrancois, L. 2000. Interleukin-7 mediates the homeostasis of naive and memory CD8 T cells in vivo. Nat. Immunol. 1:426-432.

13. Fry, T.J., and Mackall, C.L. 2001. Interleukin-7: master regulator of peripheral T-cell homeostasis? Trends Immunol. 22:564-571.

14. Tan, J.T., et al. 2001. IL-7 is critical for homeostatic proliferation and survival of naive T cells. Proc. Natl. Acad. Sci. U. S. A. 98:8732-8737.

15. Tan, J.T., et al. 2002. Interleukin (IL)-15 and IL-7 jointly regulate homeostatic proliferation of memory phenotype CD8+ cells but are not required for memory phenotype CD4+ cells. J. Exp. Med. 195:1523-1532.

16. Seddon, B., and Zamoyska, R. 2002. TCR signals mediated by Src family kinases are essential for the survival of naive T cells. J. Immunol. 169:2997-3005.

17. Seddon, B., and Zamoyska, R. 2002. TCR and IL-7 receptor signals can operate independently or synergize to promote lymphopenia-induced expansion of naive T cells. J. Immunol. 169:3752-3759.

18. Goldrath, A.W., et al. 2002. Cytokine requirements for acute and basal homeostatic proliferation of naive and memory CD8+ T cells. J. Exp. Med. 195:1515-1522.

19. Grandjean, I., et al. 2003. Are major histocompatibility complex molecules involved in the survival of naive CD4+ T cells? J. Exp. Med. 198:1089-1102.

20. Seddon, B., Legname, G., Tomlinson, P., and Zamoyska, R. 2000. Long-term survival but impaired homeostatic proliferation of naive $\mathrm{T}$ cells in the absence of p56lck. Science. 290:127-131.

21. Ge, Q., Rao, V.P., Cho, B.K., Eisen, H.N., and Chen, J. 2001. Dependence of lymphopenia-induced T cell proliferation on the abundance of peptide/ MHC epitopes and strength of their interaction with T cell receptors. Proc. Natl. Acad. Sci. U. S. A. 98:1728-1733.

22. Wang, Q., Strong, J., and Killeen, N. 2001. Homeostatic competition among $\mathrm{T}$ cells revealed by conditional inactivation of the mouse Cd4 gene.J. Exp. Med.
194:1721-1730.

23. Kassiotis, G., Zamoyska, R., and Stockinger, B. 2003. Involvement of avidity for major histocompatibility complex in homeostasis of naive and memory T cells. J. Exp. Med. 197:1007-1016.

24. Kieper, W.C., Burghardt, J.T., and Surh, C.D. 2004. A role for TCR affinity in regulating naive $\mathrm{T}$ cell homeostasis. J. Immunol. 172:40-44.

25. Troy, A.E., and Shen, H. 2003. Cutting edge: homeostatic proliferation of peripheral T lymphocytes is regulated by clonal competition. J. Immunol. 170:672-676.

26. Moses, C.T., Thorstenson, K.M., Jameson, S.C., and Khoruts, A. 2003. Competition for self ligands restrains homeostatic proliferation of naive CD4 T cells. Proc. Natl. Acad. Sci. U. S. A. 100:1185-1190.

27. Ge, Q., Bai, A., Jones, B., Eisen, H.N., and Chen, J. 2004. Competition for self-peptide-MHC complexes and cytokines between naive and memory CD8+ T cells expressing the same or different $\mathrm{T}$ cell receptors. Proc. Natl. Acad. Sci. U. S. A. 101:3041-3046.

28. Min, B., et al. 2003. Neonates support lymphopenia-induced proliferation. Immunity. 18:131-140.

29. Schuler, T., Hammerling, G.J., and Arnold, B. 2004. Cutting edge: IL-7-dependent homeostatic proliferation of CD8 $+\mathrm{T}$ cells in neonatal mice allows the generation of long-lived natural memory T cells. J. Immunol. 172:15-19.

30. King, C., Ilic, A., Koelsch, K., and Sarvetnick, N. 2004. Homeostatic expansion of T cells during immune insufficiency generates autoimmunity. Cell. 117:265-277.

31. Markholst, H., Eastman, S., Wilson, D., Andreasen, B.E., and Lernmark, A. 1991. Diabetes segregates as a single locus in crosses between inbred BB rats prone or resistant to diabetes. J. Exp. Med. 174:297-300

32. Bieg, S., et al. 1998. Genetic isolation of iddm 1 on chromosome 4 in the biobreeding (BB) rat. Mamm. Genome. 9:324-326.

33. McHugh, R.S., and Shevach, E.M. 2002. Cutting edge: depletion of CD4+CD25+ regulatory T cells 
is necessary, but not sufficient, for induction of organ-specific autoimmune disease. J. Immunol. 168:5979-5983.

34. Goronzy, J.J., and Weyand, C.M. 2001. Thymic function and peripheral T-cell homeostasis in rheumatoid arthritis. Trends Immunol. 22:251-255.

35. Dummer, W., et al. 2002. T cell homeostatic proliferation elicits effective antitumor autoimmunity. J. Clin. Invest. 110:185-192. doi:10.1172/ JCI200215175.

36. Wu, Z., et al. 2004. Homeostatic proliferation is a barrier to transplantation tolerance. Nat. Med. 10:87-92.

37. Sakaguchi, S. 2004. Naturally arising CD4+ regulatory $\mathrm{T}$ cells for immunologic self-tolerance and negative control of immune responses. Annu. Rev. Immunol. 22:531-562.

38. Shevach, E.M. 2002. CD4+ CD25+ suppressor T cells: more questions than answers. Nat. Rev. Immunol. 2:389-400.

39. Maloy, K.J., and Powrie, F. 2001. Regulatory T cells in the control of immune pathology. Nat. Immunol. 2:816-822.

40. Curotto de Lafaille, M.A., and Lafaille,J.J.2002.CD4(+) regulatory $\mathrm{T}$ cells in autoimmunity and allergy. Curr. Opin. Immunol. 14:771-778.

41. Jiang, H., and Chess, L. 2004. An integrated view of suppressor $\mathrm{T}$ cell subsets in immunoregulation. J. Clin. Invest. 114:1198-1208. doi:10.1172/ JCI200423411.

42. Roncarolo, M.G., Gregori, S., and Levings, M. 2003. Type $1 \mathrm{~T}$ regulatory cells and their relationship with CD4+CD25+ T regulatory cells. Novartis Found. Symp. 252:115-127; discussion 127-131, 203-210.

43. Bluestone, J.A., and Abbas, A.K. 2003. Natural versus adaptive regulatory T cells. Nat. Rev. Immunol. 3:253-257.

44. Curotto de Lafaille, M.A., Shen, S., Olivares-Villagomez, D., Camps-Ramirez, M., and Lafaille, J.J. 2005. Do regulatory $T$ cells play a role in the control of homeostatic proliferation? Int. Rev. Immunol. 24:1-16.

45. Murphy, K.M., Heimberger, A.B., and Loh, D.Y. 1990. Induction by antigen of intrathymic apoptosis of CD4+CD8+TCRlo thymocytes in vivo. Science. 250:1720-1723.

46. Lafaille, J.J., Nagashima, K., Katsuki, M., and Tonegawa, S. 1994. High incidence of spontaneous autoimmune encephalomyelitis in immunodeficient anti-myelin basic protein $\mathrm{T}$ cell receptor transgenic mice. Cell. 78:399-408.

47. Suri-Payer, E., Amar, A.Z., Thornton, A.M., and Shevach, E.M. 1998. CD4+CD25+ T cells inhibit both the induction and effector function of autoreactive $\mathrm{T}$ cells and represent a unique lineage of immunoregulatory cells. J. Immunol. 160:1212-1218.

48. Olivares-Villagomez, D., Wensky, A.K., Wang, Y., and Lafaille, J.J. 2000. Repertoire requirements of CD4+ $\mathrm{T}$ cells that prevent spontaneous autoimmune encephalomyelitis. J. Immunol. 164:5499-5507.

49. Curotto de Lafaille, M.A., et al. 2001. Hyper immunoglobulin $\mathrm{E}$ response in mice with monoclonal populations of B and T lymphocytes. J. Exp. Med. 194:1349-1359.

50. Olivares-Villagomez, D., Wang, Y., and Lafaille, J.J. 1998. Regulatory CD4(+) T cells expressing endog- enous $\mathrm{T}$ cell receptor chains protect myelin basic protein-specific transgenic mice from spontaneous autoimmune encephalomyelitis. J. Exp. Med 188:1883-1894.

51. Barthlott, T., Kassiotis, G., and Stockinger, B. 2003. $\mathrm{T}$ cell regulation as a side effect of homeostasis and competition. J. Exp. Med. 197:451-460.

52. Van de Keere, F., and Tonegawa, S. 1998. CD4(+) $\mathrm{T}$ cells prevent spontaneous experimental autoimmune encephalomyelitis in anti-myelin basic protein T cell receptor transgenic mice. J. Exp. Med. 188:1875-1882.

53. Saparov, A., et al. 1999. Memory/effector T cells in TCR transgenic mice develop via recognition of enteric antigens by a second, endogenous TCR. Int. Immunol. 11:1253-1264.

54. Furtado, G.C., Curotto de Lafaille, M.A., Kutchukhidze, N., and Lafaille, J.J. 2002. Interleukin 2 signaling is required for $\mathrm{CD} 4(+)$ regulatory $\mathrm{T}$ cell function. J. Exp. Med. 196:851-857.

55. Curotto de Lafaille, M.A., Lino, A.C., Kutchukhidze, N., and Lafaille, J.J. 2004. CD25- T cells generate $\mathrm{CD} 25+\mathrm{Foxp} 3+$ regulatory $\mathrm{T}$ cells by peripheral expansion. J. Immunol. 173:7259-7268.

56. Hori, S., Nomura, T., and Sakaguchi, S. 2003. Control of regulatory $\mathrm{T}$ cell development by the transcription factor Foxp3. Science. 299:1057-1061.

57. Khattri, R., Cox, T., Yasayko, S.A., and Ramsdell, F. 2003. An essential role for Scurfin in CD4+CD25+ T regulatory cells. Nat. Immunol. 4:337-342.

58. Fontenot, J.D., Gavin, M.A., and Rudensky, A.Y. 2003. Foxp3 programs the development and function of CD $4+\mathrm{CD} 25+$ regulatory T cells. Nat. Immunol. 4:330-336.

59. Brunkow, M.E., et al. 2001. Disruption of a new forkhead/winged-helix protein, scurfin, results in the fatal lymphoproliferative disorder of the scurfy mouse. Nat. Genet. 27:68-73.

60. Azzam, H.S., et al. 1998. CD5 expression is developmentally regulated by $\mathrm{T}$ cell receptor (TCR) signals and TCR avidity. J. Exp. Med. 188:2301-2311.

61. Smith, K., et al. 2001. Sensory adaptation in naive peripheral CD4 T cells. J. Exp. Med. 194:1253-1261.

62. Gudmundsdottir, H., and Turka, L.A. 2001. A closer look at homeostatic proliferation of CD4+ T cells: costimulatory requirements and role in memory formation. J. Immunol. 167:3699-3707.

63. Tanchot, C., Le Campion, A., Leaument, S., Dautigny, N., and Lucas, B. 2001. Naive CD4(+) lymphocytes convert to anergic or memory-like cells in T cell-deprived recipients. Eur. J. Immunol. 31:2256-2265

64. Bird, J.J., et al. 1998. Helper T cell differentiation is controlled by the cell cycle. Immunity. 9:229-237.

65. Gett, A.V., and Hodgkin, P.D. 1998. Cell division regulates the $\mathrm{T}$ cell cytokine repertoire, revealing a mechanism underlying immune class regulation. Proc. Natl. Acad. Sci. U. S. A. 95:9488-9493.

66. Annacker, O., et al. 2001. CD25+ CD4+ T cells regulate the expansion of peripheral CD4 $\mathrm{T}$ cells through the production of IL-10. J. Immunol. 166:3008-3018.

67. Almeida, A.R., Legrand, N., Papiernik, M., and Freitas, A.A. 2002. Homeostasis of peripheral CD4+ T cells: IL-2R alpha and IL-2 shape a population of regulatory cells that controls $\mathrm{CD} 4+\mathrm{T}$ cell numbers. J. Immunol. 169:4850-4860.
68. Ge, Q., Palliser, D., Eisen, H.N., and Chen, J. 2002. Homeostatic T cell proliferation in a T cell-dendritic cell coculture system. Proc. Natl. Acad. Sci. U. S. A. 99:2983-2988.

69. Prlic, M., Blazar, B.R., Khoruts, A., Zell, T., and Jameson, S.C. 2001. Homeostatic expansion occurs independently of costimulatory signals. J. Immunol. 167:5664-5668

70. Anderson, B.E., et al. 2004. Recipient CD4+ T cells that survive irradiation regulate chronic graft-versus-host disease. Blood. 104:1565-1573.

71. Grossman, W.J., et al. 2004. Human T regulatory cells can use the perforin pathway to cause autologous target cell death. Immunity. 21:589-601.

72. Gondek, D.C., Lu, L.F., Quezada, S.A., Sakaguchi, S., and Noelle, R.J. 2005. Cutting edge: contact-mediated suppression by $\mathrm{CD} 4+\mathrm{CD} 25+$ regulatory cells involves a granzyme B-dependent, perforin-independent mechanism. J. Immunol. 174:1783-1786.

73. Kieper, W.C., and Jameson, S.C. 1999. Homeostatic expansion and phenotypic conversion of naive $\mathrm{T}$ cells in response to self peptide/MHC ligands. Proc. Natl. Acad. Sci. U. S. A. 96:13306-13311.

74. Goldrath, A.W., Bogatzki, L.Y., and Bevan, M.J. 2000. Naive T cells transiently acquire a memory-like phenotype during homeostasis-driven proliferation. J. Exp. Med. 192:557-564.

75. Oehen, S., and Brduscha-Riem, K. 1999. Naive cytotoxic $\mathrm{T}$ lymphocytes spontaneously acquire effector function in lymphocytopenic recipients: a pitfall for T cell memory studies? Eur. J. Immunol. 29:608-614.

76. Cho, B.K., Rao, V.P., Ge, Q., Eisen, H.N., and Chen, J. 2000. Homeostasis-stimulated proliferation drives naive $\mathrm{T}$ cells to differentiate directly into memory T cells. J. Exp. Med. 192:549-556.

77. Murali-Krishna, K., and Ahmed, R. 2000. Cutting edge: naive $\mathrm{T}$ cells masquerading as memory cells. J. Immunol. 165:1733-1737.

78. Dutton, R.W., Bradley, L.M., and Swain, S.L. 1998. T cell memory. Annu. Rev. Immunol. 16:201-223.

79. Whitmire, J.K., Murali-Krishna, K., Altman, J., and Ahmed, R. 2000. Antiviral CD4 and CD8 T-cell memory: differences in the size of the response and activation requirements. Philos. Trans. R. Soc. Lond. B Biol. Sci. 355:373-379

80. Apostolou, I., and Von Boehmer, H. 2004. In vivo instruction of suppressor commitment in naive T cells. J. Exp. Med. 199:1401-1408.

81. Mucida, D., et al. 2005. Oral tolerance in the absence of naturally occurring Tregs. J. Clin. Invest. 115:1923-1933. doi:10.1172/JCI24487.

82. Fehervari, Z., and Sakaguchi, S. 2004. Development and function of CD25+CD4+ regulatory T cells. Curr. Opin. Immunol. 16:203-208.

83. Mombaerts, P., et al. 1992. Mutations in T-cell antigen receptor genes alpha and beta block thymocyte development at different stages. Nature. 360:225-231.

84. Koopman, G., et al. 1994. Annexin V for flow cytometric detection of phosphatidylserine expression on B cells undergoing apoptosis. Blood. 84:1415-1420

85. Gavrieli, Y., Sherman, Y., and Ben-Sasson, S.A. 1992. Identification of programmed cell death in situ via specific labeling of nuclear DNA fragmentation. J. Cell Biol. 119:493-501. 